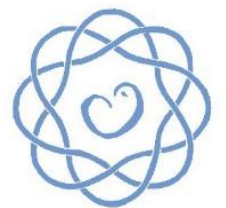

DOI: 10.24946/IJPLS.20.19.00.00.181108

https://www.journalprenatalife.com

\title{
Title: Prenatal Human Modification, Designing Babies and the End of Homo Sapiens.
}

\author{
Author: Olga Gouni ${ }^{1}$
}

Affiliation:

cosmoanelixis, Prenatal \& Life Sciences, Athens, Greece

Prenatal Sciences Research Institute, Athens, Greece

The rapid pace of genetic research guarantees that we will see genetically manufactured babies before the end of the century. Eric G Swedin (Swedin, 2006)

\begin{abstract}
Since 1978, the year when Louise Joy Brown, the first human baby conceived by IVF was born, the scientific world has seen a huge explosion in the knowledge gained in the fields of genetics and genetic research and technology, biology, engineering, Artificial Intelligence and the such. Hybrid fields came into appearance and words like biogenetics, human engineering, human enhancement and Reprogenetics (Silver 2000) to mention a few have entered our vocabulary. ART was once a word to describe the talented outcomes of painters and sculptors. Today, it is a common word to refer to Artificial Reproductive Technology. Back in 1932, Aldous Huxley (Huxley, 1932) published wellknown dystopian novel "Brave New World" and set the futurist genetically modified citizens, members of an intelligence-based social/political hierarchy into context, anticipating the huge scientific developments in reproductive technology which now are a reality. Pre-implantation Genetic Diagnosis (PGD), Cloning, Germ-line Therapy, Human Enhancement and (True) Designer Babies are here to stay. Parents, today, are seduced into a possibility of selecting the particular genes that will render their children healthy, intelligent and powerful, thus controlling their children identity of being. They turn to cloning and baby design to provide for their sick children. Reprogenetics is being practiced in an effort to control the birth of mentally retarded humans and postnatal interventions are here to allow certain characteristics to be integrated as human enhancements.
\end{abstract}

Studying the psychological and socio-relational consequences of traumatic preconception, prenatal, birth and early postnatal experience, what we are to see as a result of the new, here to stay scientific, technological and laboratory interventions that

${ }^{1}$ Corresponding author email: info@cosmoanelixis.gr 
may turn parenthood into an act of gardening or cultivation with decision-making based on eugenic genetic control is just a small fraction ${ }^{2}$. Is there a line to be drawn? Is this the end of Homo Sapiens? Has already the Posthuman been conceived? Will the intention of health support become the front cover for hidden sociopolitical agendas, leading to the extinction of democracy and the sovereignty of those who have and can?

Keywords: PGD (Preimplantation Genetic Diagnosis), Cloning, Germ-line Therapy, Human Enhancement, Post-humanity, Designer Baby, Genetic Engineering, Genomic Science, Reprogenetics, Prenatal Human Modification, Bioethics.

\section{Introduction}

\section{"The price of anything is the amount of life we exchange for it"}

Henry David Thoreau

More than 40 years passed since the first human baby was conceived and born through science rather than the loving act of mother and father becoming one. The moment was hailed as a miracle raising hope for infertile couples but also sent shockwaves to various circles, church and medical profession among them raising ethical questions. Since then, science has run kilometres. Crisp (Clustered Regularly Interspaced Palindromic Repeats) (Begley, 2018), is the fastest, easiest and cheapest method of manipulating the genes and provides scientists with molecular tools which can precisely target and cut any kind of genetic material. (Baylis, 2019) What once seemed to be Science Fiction is now a reality that enables scientists to manipulate the code of life in any organism on the planet, humans included, thus being able to change the fundamental chemistry of who we are.

Just one year ago, in November 2018, at the National Academy of the Sciences summit, He Jiankui, a Chinese biophysicist, announced the successful application of human germline editing that led to the birth of Lulu and Nana, twins (He Jiankui, 2018). He Jiankui used Crisp technology to edit the embryo of the HIV+ father and HIV- mother so that the child can have the sure trait of the ability to resist HIV infections. He Jiankui also finally revealed that his research team had so far injected Crisp systems into 31 more cases developed to the blastocyst stage. The announcement was received with a lot of scepticism (Bulluck, 2109), a lot of voices among which that of the Nobel laureate and summit chair David Baltimore (Saey, 2019) who spoke about the "non-responsible application of human germline editing", the experiment was paused, and investigations started.

\section{From drosophila to Humans?}

What we have recently witnessed as a reality in the field of genetics can be traced back to the time when Hermann J Muller, who won the Nobel for medicine in 1946, changed the understanding of the gene and revolutionized the research in the genetics when he demonstrated that radiation from X-rays would change the genetic makeup of fruit flies (drosophila) and create mutations passed to the generations that follow. This was the beginning of an era when humans altered the genetics of another creature. His Nobel award came 20 years after Muller's findings (Muller, 1927, 1928), got published in Science

\footnotetext{
${ }^{2}$ The paper will risk posing questions for philosophical and ethical considerations, hoping to sensitize those involved so that human progress and consciousness evolution can continue on health grounds.
} 
back in 1927. His publication attracted a lot of attention at the time and his work connecting radiation and mutation- which actually altered the heredity of flies- became an eye-opener for scientists to explore the vast possibilities of genetics. Of course, Muller was also to speak and publish about the threats radiation posed on people, much sooner than most other scientists did. What Muller introduced as so innovative 100 years ago seems quite simple and commonplace today (Calabrese E. J. ,2018).

However, Muller was not the first one to experiment and research into improving human possibilities.

\section{Nature the Great Scientist V human practices}

Throughout history, the interplay between Nature and organism (McMurray, 2016) has introduced changes which enabled organisms better adapt and maintain life on our planet. Such processes took long to appear and passed through manifold changes along the way, dropping and assuming qualities.

Studying the social and anthropological aspects of humanity (Bashford, 2010), we can also see that people tried to get desirable traits by manipulating sexual act. Thus, noble people got married and had children of noble origin, people of specific traits were together with others who also presented specific traits to create offspring with desirable qualities. Positive eugenics has been an ancient practice as ancient as negative eugenics, which included marriage prohibitions, forced isolations etc to avoid passing undesirable traits to the next generation (Hansen et al, 2001).

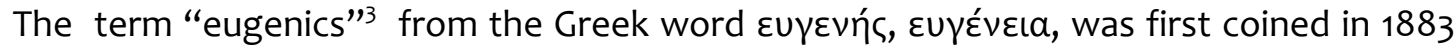
by Sir Francis Galton (Sir Francis Galton, 1883, 1904), a British polymath, child prodigy, half-cousin of Charles Darwin and the one who first introduced other well-known terms, beyond "eugenics" that is "Nature Versus Nurture" and synaesthesia and he was the one who founded psychometrics but also did research on the power of prayer.

The definition of "Eugenics" given in those early times described "the science which deals with all influences that improve the inborn qualities of a race; also, with those that develop them to the utmost advantage". According to Sir Galston, eugenics "takes cognisance of all influences that tend in however remote a degree to give the more suitable races or strains of blood a better chance of prevailing speedily over the less suitable than they otherwise would have had."

Still in practice today, in other fields such as agriculture and animal breeding, apart from humans, sterilization, contraception, genetic selection, prenatal testing followed by abortion, prenatal screening and testing for anomalies, chorionic villus sampling, amniocentesis, donor insemination and other suchlike practices are in use to reduce or eliminate undesirable outcomes among the human population. And the memory of Nazi experiments (Kevles, 1999) in their effort to create the Arian Race is still fresh to remind us of the sensitive line not to be crossed.

\footnotetext{
${ }^{3}$ Eugenics: Applied science or the biosocial movement which advocates the use of practices aimed at improving the genetic composition of a population. Usually refers to human populations. Definition from: Unified Medical Language System $\leftrightarrow$ (Psychological Index Terms) at the National Library of Medicine
} 


\section{Designer Babies}

The term "designer baby" became part of the vocabulary in the mid-to-late 1980 s. At that early use of the term there was no reference to the genetics, gene editing, modification, enhancement etc. It reflected a tendency that appeared at the time to describe the expensive and exclusive, as part of the marketing frenzy that asked for designer clothes, kitchens, bed-linen etc and finally designer pets and designer babies, moving from the inanimate sphere to that of living entities and finally human beings.

At the time, a designer baby was the "perfect little creature who was welcomed into the world with matching curtains, cot covers, changing mats and super-sprung buggies" and adorned with upscale designer baby products like "baby splashes, lotions, oils, shampoos, fragrances, lip balms and special soaps”(Baylis, 2019).

From that point on, the term took on a new meaning. Using the same technology already in use for the modification of vegetables or animals -and the advances that will see the light in the future- people will be able to edit or reshuffle genes so that they make sure that the baby will present specific characteristics. According to Oxford English dictionary, a design baby is " $a$ baby whose genetic makeup has been artificially selected by genetic engineering combined with in vitro fertilization to ensure the presence or absence of particular genes or characteristics." (2). A design baby is a GM baby, unique not by chance, the result of the interplay of the environment and the baby, but by design. What is most is that the baby will be in part at least "produced" outside the womb. And since the whole process will be done by a specific company that first receives an order by a "client" for this baby and charges fees for their standard or customised work, the baby will be a "product" available to those who can afford with monumental societal and relational consequences.

Do we become a commodity? Have we thought of the impact this alone could have on the psychospiritual development of all involved? (Agar, 2006)

\section{Cloning}

Another biotechnology-cloning-may enable the selection of children's characteristics. Although some people may view cloning (Plus, 2011, Latham 2005) as a last-ditch response to infertility, others may see it as a way of selecting the characteristics of their child. This choice would be exercised through the choice of the person to be cloned. For example, you might pursue physical attractiveness on your child's behalf by using a somatic cell from a top model or Hollywood star, or the Nobelist cognitive qualities and/or the Picasso's artistic skills. The religious opposition is easily understood (Bainbridge, 2003), but beyond that cloning (Mumford, 2013) raises lots of identity issues, challenges efforts to resurrect from the Dead with all its unforeseen consequences, has become part of the culture today with lots of debates on how clones could be used for warfare and lots of films have been produced around the theme. Furthermore, it raises an issue of violation of the rights of the child (the argument, stands true in all cases) who cannot give a consent for any action, no matter what it is, done to him/her even to his/her best. Consent is a crucial topic in bioethics and any person needs to give his/her own consent for any action performed on him/her from before. And in cases of curators or guardians, they need to be wise enough to make decisions for those they look after for the best of their interests. Certainly, the debate about this wisdom is the guiding force behind the decisions that parents make for their offspring is big. In the field of Prenatal Psychology, control issues and power games which disempower the 
child born are evident as well as all the consequences well-documented now for those conceived or born to execute specific goals on behalf of others or those born after a parental preference for an enhanced child with all known unpleasant effects on the born child.

At the same time, there is no need for any sperm. Does this mean that we are heading towards a new era of females to be the dominant sex? Besides, there are major concerns about the health of clones. Animal clones suffer from a variety of problems that some scientists connect with incomplete reprogramming of somatic cell DNA or damage inflicted by the process of nuclear transfer. Human clones (Humber, 1998) may also suffer from these problems. ${ }^{4}$

\section{Does your genetic code define your destiny?}

And this brings forward another significant issue: Genetic Determinism and the old dilemma Nature or Nurture.9 Genetic determinism supports the notion that an organism's significant characteristics depends on its genes, with environmental influences playing a negligible, or small, role. With the findings from the field of Epigenetics, this view is now widely recognized as false. Organisms emerge from a complex interaction of genes and environment. Roger Federer, one of the greatest tennis players in history is the authentic outcome of such very complex interplay. His clone would be subjected to different environmental influences from the original, meaning that the clone might easily lack any interest in or aptitude, or ability, for tennis.

Apart from the physical, Ishiguro Kazuo, Literature Nobelist, (Ishiguro, 2005) in his book "Never Let Me Go" casts light on the destiny of those created to act as organ donors to the ones who paid for them (clones) and provides food for thought around the nature, rights and life of such a dystopian possibility.

William Kent Krueger (Krueger, 2014) in his book "Ordinary Grace", shows the meaning in life as each of the characters in this gripping story has a burden to bear, but many of them rise above their challenges to make the world somehow better through simple acts of courage and kindness.

\section{Getting rid of the disease}

Of course, the argument that specific diseases will stop from being handed down from generation to generation is the one which is to be used. And it may be true. Although we must learn from mutated food in the supermarkets and think again. Many genes have more than one effect which means that the effect we intend may be accompanied by others of which we become aware only later. Since epidemiological studies are difficult to happen and spread over generations, it may be too late when we realize the side effects of tampering genes, especially when we edit multiple genes to achieve the specific traits in mind.

The use of preimplantation genetic diagnosis to avoid passing on a disease to a child is already extensively used posing ethical questions (Josefson, 2000), causing psychological issues and relational challenges and certainly adding up abortion rates as it reflects maternal environment preferences or/and rejection, both having been extensively studied within the field of Prenatal Psychology.

\footnotetext{
${ }^{4}$ http://www.aaas.org/spp/sfrl/docs/cloningstatement.shtml
} 


\section{Saviour siblings}

Adam Nash is the world's first known designer baby. Using a "pre-implantation process", scientists genetically selected his embryo so that he would have the right cells to save the life of his dying sister who suffered from Fanconi-anaemia, an extremely rare genetic disease that would eventually kill (Verlinsky et al, 2001), (Pennings et al, 2002), (Van de Velde et al, 2004), (Boyle R, Savulescu J., 2001), (Springs, Savulescu, 2002). It would be very interesting to see how these intentions might affect saviour siblings and what happens to their lives later, both within the family and out, in the society. (Devolver. 2005). The editor of the "Bulletin of Medical Ethics", Richard Nicholson stated that "we are not creating the saviour sibling to be a child in the correct sense. We have created itdesigned it - to be a source of spare parts for an existing child." "Where do we draw a moral distinction between slavery... and creating what I prefer to call slave siblings". (Nicholson, 2003). Suzi Leather (Leather, 2003) says we might equally call them "spare part sisters" or "bred to order brothers".

And although good intentions as the above-mentioned ones of parents for example wishing the best for their children at least health wise (Madanamoothoo A, 2011), the opposite polarity is also at play. As Robert G. Edwards the scientist who helped in the $1^{\text {st }}$ tube baby said in 2003 "It was a fantastic achievement, but it was about more than infertility. It was also about issues like stem cells and the ethics of human conception. I wanted to find out exactly who was in charge, whether it was God himself or whether it was scientists in the laboratory... It was us!"

Gene Modification technology in the hands of those who are not motivated by the best intentions can put humanity at risk by selecting traits to manifest in babies who can make the best soldiers, Mars explorers, sex mates, brilliant minds etc with unforeseen social consequences.

\section{Transhumanism}

In 1990, Max More, one of the main transhumanists, defined "Transhumanism5 as a class of philosophies of life that seek the continuation and acceleration of the evolution of intelligent life beyond its currently human form and human limitations by means of science and technology, guided by life-promoting principles and values.". The movement (Bostrom, 2005) sees human species in its current form as being in a rather comparatively early phase.

Transhumanists are transitional human beings, an intermediary form between the human and posthuman the "earliest manifestation of new evolutionary beings" as F.M. Estfandiary (FM 2030) says. They have "prostheses, plastic surgery, intensive use of telecommunications, a cosmopolitan outlook and a globetrotting lifestyle, androgyny, mediated reproduction (such as in vitro fertilization), absence of religious beliefs, and a rejection of traditional family values."

How this can happen? Using the biotechnology at hand the insertion of a non-human gene, a gene from another species, can be inserted bringing a more extreme change but also extreme outcomes such as enhanced night/ full spectre vision, extreme hearing

\footnotetext{
${ }^{5}$ https://www.theverge.com/a/transhumanism-2015/history-of-transhumanism
} 
qualities, extreme lifting/ running/ endurance skills etc. Using CRISPR-Cas9 technology such transformations are quite easy and without using embryonic stem cells.

Present biotechnology has led to smart skin , the world's fastest stretchable, wearable integrated circuits that can be worn like a temporary tattoo to monitor people's vital signs remotely, in intensive care units, microchip implants to enable his creator Amal Graafstra, founder of bio-hacking company Dangerous Things to download information to and from his phone, hearing colour antennas like the one Neil Harbisson who suffers from achromatopsia wears to hear colour, bionic eyes that could help up to $85 \%$ of clinically blind people, to mention some of the ever evolving technology of today.

Humanity ${ }^{6}$ is an NGO that promotes discussion of possibilities for the improvement of human capacities, seek academic acceptance and co-ordinate action in the field. $\mathrm{H}+$ is the symbol that people in support of transhumanism use to speak about better humans, already called "Homo Evolutis", a version of a person that is beyond human.

\section{Post Humans}

Post humans (Ferrando, 2014) are possible future beings whose basic capacities exceed those of present humans. They could be completely synthetic artificial intelligence, or they could be enhanced uploads or they could be the result of making many smaller but accumulatively profound augmentations to a biological humans, using advanced nanotechnology (, genetic engineering, psychopharmacology, anti-aging therapies, neural interfaces, advanced information management tools, memory enhancement drugs, wearable computers and cognitive techniques. Post humans are considered to have experiences that we can not even imagine and live without bodies as information patterns on super-fast computer networks, enjoying different mind architectures.

\section{Are designer babies "posthumans"?}

Francis Fukuyama (Fukuyama, 2002) thinks that genetic enhancements may change our descendants to such an extent that they lose their humanity. According to Fukuyama, "environmental influences operate only within limits set by genes", meaning that even ambitious education programs leave their subjects' humanity intact. A genetically enhanced child is more fittingly described as a "posthuman."

Are geniuses accidental posthumans because they're above the norm? Transhumanists see designer babies as a goal rather than an issue (Hansson, 2008).

\section{Are Designer babies a threat to society by creation of a "master-race"}

Some of the most challenging moral and ethical questions about a licence to design babies concern the societies it might lead to. The movie Gattaca depicts a future in which genetically enhanced people take the lead, viewing unenhanced people as fit only to clean up after them. Liberal democracy is a cooperative venture in which all are seen as having something to offer.17 Will genetic enhancement bring this social arrangement to an end, creating societies in which unenhanced people are viewed by their genetic superiors in much the same way that we currently view guinea pigs?

Dividing humans in two different classes: the "desirables", the "superior race", the laboratory-engineered "valid" and the "undesirables", the "inferiors" or the genetically

\footnotetext{
${ }^{6}$ https://whatistranshumanism.org
} 
inferior "invalid" may lead people marked as belonging to the $2^{\text {nd }}$ group to be at risk of exposure to harmful acts of discrimination, stigma and marginalization.

\section{Ectogenesis, Artificial Wombs and Daedalus}

All of us remember the ancient Greek myth of Daedalus and Icarus (Haldane, 1924). Daedalus, father of Icarus crafted wings out of bird feathers, wax and string in his effort to escape from King Minos and as they raised up in the sky, the hot sun melted the wax causing the destruction of the son whom the father wished to save. A great metaphor to let us think and think again about our motives and our actual deeds and their impact on those we wish to protect.

Beyond the myth and its own teachings, J.B.S. Haldane, a British scientist back in 1924, chose the name of Daedalus to emphasize the quality of the scientist who "is not concerned with Gods and is not haunted by old taboos". He was the first to speak about ectogenesis and describe how human pregnancy could one day give way to artificial wombs foreseeing that by 2074 ectogenesis (James, 1987) will be the main technique human babies will be born with "... less than 30\% of children now born of women". In 1951, Dupont and Schwarz produced the first ectogenetic child and today we are closer to perfecting the technology that would make Haldane's vision into reality. Dr Hung-Ching Liu of the Weill Medical College at Cornell University has engineered endometrial tissue in the lab to create an artificial uterine lining to implant an embryo. Due to legislation, he allowed -as he said- the baby to grow for 6 days. More research experiments are being done in other laboratories, while such research with animals is thriving. The time when babies will be gestated in artificial wombs is around the corner, bringing motherhood and mother-baby bonding into a new dimension (Rosen, 2003).

\section{Where do we draw the line?}

Beyond that, the question to ask is "Is there a line to be drawn" The issue is not just an issue of what health and disease is, but also what life is and why is there life on this planet. We need to find a good balance between what supports life and what destroys it (Turners, Gouni, 2018). Then, there are questions concerning power, exertion of power and what should power be used for.

Even when talking about health and disease, it is hard to find definitions of disease suitable to serve as a moral guideline for genetic technologies. Social constructivists consider diseases to be states to which society takes a negative attitude. Cancer seems to satisfy the requirements of this definition, but so might homosexuality and practicing a religion different from the norm in another society. Objectivist accounts avoid these difficulties by making the definition of disease independent of our attitudes. The view that "I suffer from a disease when I fail to perform any of my biological functions" is not enough any longer as human experience is not restricted to our mere biology but extends to other, non-physical spheres as well, on an individual level, and it extends to include social and cultural aspects as well.12

A further moral complication emerges from the different approaches to treating disease and those who suffer from them. Genetically modifying an embryo to remove a gene linked with a higher than average risk of asthma may prevent asthma, but it need not prevent the existence of the person who might have suffered from it. Compare this with the use of PGD to avoid having a child at a high risk of asthma. This seems to prevent the disease only by preventing the patient's existence. Exactly as we abort a child after screening if the child presents a syndrome or other disease. 
Adding an extra copy of the NR2B gene to a human embryo, on the other hand, has the quite distinct aim of producing someone who, in some area, functions beyond a level considered normal for human beings and as such qualifies as an "enhancement."

\section{Is there another way?}

Is the way parents rear a child also a way of designing a child?

There is a very important principle to be considered here. That of respect versus that of manipulation and intervention to get wanted results. Unfortunately, we have seen, and we have heard the sad stories of pain every time a baby is faced with interventions in their pre/perinatal early postnatal experience and how this is carried on in their whole life as adults (Gouni et al, 2005-2018). The Hippocratic principle "Do no harm" is by itself a safe guideline to be used in all situations. No matter what we are talking about, technology or natural non-intervention conception, gestation and upbringing of children, this simple rule can do miracles.

We are not to stop evolution and human development. Life goes on and up, hopefully. But we need to learn from our experience and our arrogant moments of our past so that we can respect life on Earth.

Parental environments and societal environments have always wished for the best of their offspring. That's why they provide for their schooling and paedia (education), arrange for their children's settings, nutrition, relations, resources available etc. And this is what has led us to this point we are now.

\section{Epilogue}

Providing the best for our children starts with looking after and healing the issues of the generation living today. Providing for the generation of children already born. Providing for the new adults who are to invite newcomers in their family environment, even though the concept of family is in a transformation form. Support them so that they can experience ample love, attention, opportunity, education, healthy environments of cocreation, co-operation and peace so that they can attain high levels of spirituality which by itself can provide the compass which will take future generations to elevated heights on an individual level as well as higher collective consciousness.

The moral parallel between loving conception, gestation, birthing and upbringing of children and genetic enhancement will be drawn if all science raises its own responsibility level and the market or politicians understand their essential role in human communities.

The message sent out to mankind by the Peace Nobelist Elie Wiesel ${ }^{7}$ in 1986 is a message of peace, atonement and human dignity are now more significant than ever: "We must not see any person as an abstraction. Instead, we must see in every person a universe with its own secrets, with its own treasures, with its own sources of anguish, and with some measure of triumph".

\section{References (extensive)}

1. Agar N, 2006, Action Bioscience

\footnotetext{
${ }^{7}$ https://www.bu.edu/federal/2016/07/03/elie-wiesel-hon-74-spokesman-for-peace-and-humanrights-dies-at-87/
} 
2. Bainbridge William Sims, 2003, Religious Opposition to Cloning, Journal of Evolution and Technology - Vol. 13 - Oct. 2003, http://jetpress.org/volume13/bainbridge.htm

3. Bashford, Alison; Levine, Philippa (3 August 2010). The Oxford Handbook of the History of Eugenics. Oxford University Press. p. 327. ISBN 978-0199706532.

4. Baylis Francoise, 2019, Altered Inheritance: CRISPR and the Ethics of Human Genome Editing 1st Edition, Harvard college, 9780674241961 (EPUB), 9780674241978 (MOBI), 9780674241954 (PDF), USA

5. Begley, Sharon; Joseph, Andrew (17 December 2018). "The CRISPR shocker: How genome-editing scientist He Jiankui rose from obscurity to stun the world". Stat News. Retrieved 17 December2018.

6. Bostrom, Nick (2005). "A history of transhumanist thought", Journal of Evolution and Technology. Retrieved February 21, 2006.

7. Boyle R, Savulescu J. 2001, Ethics of using preimplantation genetic diagnosis to select a stem cell donor for an existing person. BMJ 2001; 323: 1240-1243.

8. Bulluck, Pam (14 April 2019). "Gene-Edited Babies: What a Chinese Scientist Told an American Mentor". The New York Times.

9. Calabrese E. J. (2018). Muller's nobel prize research and peer review. Philosophy, ethics, and humanities in medicine: PEHM, 13(1), 15. doi:10.1186/s13010-018-0066-z

10. D Josefson, 2000, Couple select healthy embryo to provide stem cells for sister. British Medical Journal 2000; 321: 917.

11. Devolver K., 2005, Preimplantation HLA typing: Having children to save our loved ones. Journal of Medical Ethics 2005; 31: 582-586.

12. Dickens, BM., 2005, Preimplantation genetic diagnosis and "saviour siblings". Inter J Gynecol Obstet 2005; 28: 91-96.

13. Dobson R., 2000, “Designer baby” cures sister. BMJ 2000; 321: 1040.

14. Edwards B., 2004, Ethics of PGD: thoughts on the consequences of typing HLA in embryos. RBMOnline 2004; 9: 222.

15. ESHRE Taskforce 9: the application of preimplantation genetic diagnosis for human leukocyte antigen typing of embryos. Human Reproduction 2005; 20: 845-847.

16. F. Shenfield, G. Pennings, P. Devroey, C. Sureau, B. Tarlatzis, J. Cohen, and The ESHRE Ethics Task Force Taskforce 5: preimplantation genetic diagnosis

17. Ferrando, Francesca, 2014, "The Body" in Post- and Transhumanism: An Introduction. Peter Lang, Frankfurt: 2014

18. FM-2030, 1989, Are You a Transhuman? (New York: Warner Books, 1989)

19. Fukuyama Francis, 2002, Our Posthuman Future: Consequences of the Biotechnology Revolution. New York, NY: Farrar, Straus and Giroux. ISBN 0-37423643-7

20. He Jiankui, Laura; Zhang, Jane; Moon, Louise (29 November 2018). "Who are the investors supporting He Jiankui, the Chinese scientist behind the gene-edited babies?". South China Morning Post.

21. Galton Francis, Sir, 1883, Inquiries Into Human Faculty and Its Development. Macmillan.

22. Galton, Francis (July 1904). "Eugenics: Its Definition, Scope, and Aims". The American Journal of Sociology. X (1): 82. Bibcode:1904Natur..70...82.. doi:10.1038/070082a0. 
23. Gluckman E, Rocha V. Cord blood transplantation: state of the art. Haematologia 2009; 94: 451-454.

24. Gouni, 2005, Prebirth Psychology in Action: Presentation at the $16^{\text {th }}$ International Congress ISPPM, 2005, "The Anthropology \& Psychology of Pregnancy \& Birth" Heidelberg, Germany

25. Gouni, 2007, How we and the world turn a blind eye! It is time to welcome our children! (Moscow congress, 2007)

26. Gouni, 2007, Prenatal and Perinatal Experience and Autonomy: Presentation at the Greek-Cypriot Congress for Children with Disabilities, 2007, THEOTOKOS, Athens, Greece

27. Gouni, 2008, From the Heart to the Ear: Presentation at the Second European Congress of Early Prevention in Children with Verbal Communication Disorders, 26-28 September, 2008 Sofia, Bulgaria Organized by: The NBU (New Bulgarian University) Sofia, Bulgaria, The IEPSP (Institute for Experimental Phonetics and Speech Pathology, Belgrade, Serbia) The P.A.L.O. (The Hellenic Organization of Hearing, Speech Therapy \& Communication Disorders, Patra, Greece

28. Gouni, 2008, It is Never too Late! Now is the Moment! Presentation at the XVIIIth International ISPPM Congress: Prevention- Early Dialogue, 2008, Heidelberg, Germany.

Gouni, 2008, Prenatal Cont ${ }^{\circledR}$ acts for a Lifetime: Presentation at the Parma congress, 2008

29. Gouni, 2011, The Roots that Sprout Wings, Presentation at ISPPM congress in Frankfurt

30. Gouni Olga, Slobodan Sekulic, \& Anastasia Topalidou. (2016). The Contribution of Prenatal Psychology to Our Understanding about Prenatal Dynamics and Fetal Behaviour. Psychology Research, 6(12), 693-711.

31. Green Ronald M., 2007, Babies by Design: The Ethics of Genetic Choice, Yale University Press, ISBN 978-0-300-12546-7

32. H. Van de Velde, I. Georgiou, M. De Rycke, R. Schots, K. Sermon, W. Lissens, P. Devroey, A. Van Steirteghem, and I. Liebaers, 2004, Novel universal approach for preimplantation genetic diagnosis of -thalassaemia in combination with HLA matching of embryos. Human Reproduction 2004; 19: 700-708.

33. Haldane, 1923, DAEDALUS or Science and the Future. A paper read to the Heretics, Cambridge, on February 4th

34. Haldane, 1924, DAEDALUS or Science and the Future. Book, England

35. "Selected Genetic Papers of JBS Haldane", New York: Garland, 1990

36. Hansen, Randall; King, Desmond (1 January 2001). "Eugenic Ideas, Political Interests and Policy Variance Immigration and Sterilization Policy in Britain and U.S". World Politics. 53 (2): 237-263. doi:10.1353/wp.2001.0003. JSTOR 25054146.

37. Handyside AH, Kontogianni EH, Ardí K, Winston RM. 1990, Pregnancies from biopsied human preimplantation embryos sexed by $\mathrm{Y}$-specific DNA amplification. Nature 1990; 344, 768-770.

38. Handyside AH, Pattinson JK, Penketh RJ, Delhanty JD, Winston RM, Tuddenham EG., 1989, Biopsy of human preimplantation embryos and sexing by DNA amplification. Lancet 1989; 333: 347-349.

39. Hansen M, Bower C, Milne E, de Klerk N, Kurinczuk JJ. , 2005, Assited reproductive technologies and the risk of birth defects-a systematic review. Hum Reprod 2005; 20: 328-338. 
40. Hansson SO. 2008, Three Bioethical Debates in Sweden. Cambridge Quarterly of Haelthcare Ethics 2008; 17: 261-269.

41. Humber, James M., Almeder, Robert (1998). Human Cloning. Springer Science \& Business Media. p. 10. ISBN 9781592592050.

42. Huxley, Aldous, 1932, Brave New World. New York: Harper Brothers

43. Ishiguro Kazuo, 2005, Never let me go, Faber and Faber, 1-4000-4339-5 (first edition, hardback)

44. James, David N. (1987). "Ectogenesis: a reply to Singer and Wells". Bioethics. 1 (1): 80-99. doi:10.1111/j.1467-8519.1987.tboooo6.x. PMID 11649763

45. Drexler Eric, 1992, Nanosystems: Molecular Machinery, Manufacturing, and Computation, (New York: John Wiley \& Sons)

46. Kevles D. J. (1999). Eugenics and human rights. BMJ (Clinical research ed.), 319(7207), 435-438. doi:10.1136/bmj.319.7207.435

47. Knoepfler Paul, 2015, Gmo Sapiens: The Life-changing Science Of Designer Babies, World Scientific Publishing Co, Pte, Ltd, ISBN 978-9814667005

48. Krueger, W. K. (2014). Ordinary Grace: A novel. New York: Atria Paperback.

49. Kuliev A, Rechitsky S, Tur-kaspa I, Verlinsky Y. Preimplantation Genetics: Improving Access to Stem Cell Therapy. Annals of New York Academy of Sciences 2005; 1054: 223-227.

50. Kuliev A, Rechitsky S, Verlinsky O, Tur-Kaspa I, Kalakoutis G, Angastiniotis M, Verlinsky Y. , 2005, Preimplantation diagnosis and HLA typing for haemoglobin disorders. RBM Online 2005; 11: 362-370.

51. Kuskonmaz B, Gocer S, Ersoy-Ewans S, Cetin Ozman F, Cetin M, Uckan D., 2007, Hyperacute graft-vs.-host disease after related HLA-identical umbilical cord blood transplantation. Pediatrics Transplantation 2007; 11: 818-820.

52. Latham, K. E. (2005). "Early and delayed aspects of nuclear reprogramming during cloning, Biology of the Cell. pp. 97, 119-132

53. Leather S. 2003, Saviour siblings. Is it right to create a tissue donor baby? London: Progress Educational Trust, 2003. http://www.progress.org.uk/Events/ PastEventsSSL.html

54. Lie RT, Lyngstadaas A, Orstavik KH, Bakketeig LS, Jacobsen G, Tanbo T., 2005, Birth defects in children conceived by ICSI compared with children conceived by other IVF-methods; a meta-analysis. Int J Epidemial 2005; 34: 696-701.

55. Madanamoothoo A, 2011, Saviour-sibling and the psychological, ethical and judicial issues that it creates: should English and French legislators close the Pandora's Box? Eur J Health Law. 2011, May;18(3):293-303

56. Mastenbroek S, Twisk M, van Echten-Arends J, et al. , 2007, In vitro fertilization with preimplantation genetic screening. The New England Journal of Medicine 2007; 357: 9-17.

57. MD Damewood, 2001, Ethical Implications of a New Application of Preimplantation Diagnosis JAMA 2001; 285: 3143-3144.

58. McMurray Bob(2016) Nature, nurture or interacting developmental systems? Endophenotypes for learning systems bridge genes, language and development, Language, Cognition and Neuroscience, 31:9, 10931097, DOI: 10.1080/23273798.2016.1227859 
59. Muller HJ. 1927, Artificial transmutation of the gene. Science. 1927c;66(1699):84-7.

60. Muller HJ., 1927, Effects of X-radiation on genes and chromosome. Presented the American Association for the Advancement of Science Meeting, Nashville TN, December 1927. Lilly library, Muller mss, Indiana University, Bloomington, IN, $1927 a$.

61. Muller HJ., 1927, Letter to Hartman. Lilly library, Muller mss. Indiana University, Bloomington, IN. October 28, 1927e.

62. Muller HJ., 1950, Some present problems in the genetic effects of radiation. J Cell Comp Physiol. 1950;35(Suppl 2):9-70

63. Muller HJ., 1928, The effects of X-radiation on genes and chromosomes. Science. 1928c;67:82.

64. Muller HJ. , 1927, The problem of genic modification. Presented in Berlin, 5 th Genetic Congress 1927a. Bloomington, IN: Lilly library, Muller mss, Indiana University; 1927d.

65. Muller HJ., 1928, The production of mutations by X-rays. Proc Nat Acad Sci. 1928a; 14(9):714-26.

66. Mumford, James (2013). Ethics at the Beginning of Life: A Phenomenological Critique. OUP Oxford. ISBN 978-0199673964.

67. Munné S, Gianaroli L, Tur-Kaspa LL, et al, 2007, Substandard application of preimplantation genetic screening may interfere with its clinical success. Fertility and Sterility 2007; 88: 781-784.

68. Nerlich B, Johnson S, Clarke D., 2000, The first 'designer baby': The role of narratives, clichés and metaphors in the year 2000 media debate. Science as Culture 2003; 12: 471-498.

69. Nicholson R., 2003, Saviour siblings: is it right to create a tissue donor baby? London: Progress Educational Trust, 2003. http://www.progress.org.uk/ Events/PastEventsSSL.html

70. Pennings G, Schots R, Liebaers I., 2002, Ethical considerations on preimplantation genetic diagnosis for HLA typing to match a future child as a donor of haematopoietic stem cells to a sibling. Human Reproduction 2002; 17: 534-538.

71. Preimplantation donor selection (editorial). The Lancet 2001; 358: 1195.

72. Plus, M. (2011). "Fetal development". Nlm.nih.gov. Retrieved 31 October 2011.

73. Querol S, Mufti GJ, Marsh SGE, Pagliuca A, Little A-M, Shaw BE, et al. Use of cost effectiveness analysis to determine inventory size for a national cord blood bank. Med Decis Making 2009; 94: 536-41.

74. Reefhuis J, Honein MA, Schive LA, Correa A, Hobbs CA, Rasmussen SA., 2009, Assisted reproductive technology and major structural birth defects in the United Status. Hum Reprod 2009; 24: 360-366.

75. Robertson JA, Kahn JP, Wagner JE., 2002, Conception to obtain hematopoietic stem cells. Hastings Cent Rep 2002; 32: 34-40.

76. Robertson JA, Kahn JP, Wagner JE. , 2002, Contraception to obtain hemotopoietic stem cells. Hastings Cent Rep 2002; 32: 34-40.

77. Rocha V, Gluckman E. , 2007, Outcomes of transplantation in children with acute leukaemia. The Lancet 2007; 369: 1906-1908.

78. Rosen Christine, 2003, Why not artificial Wombs, New Atlantis 
79. Saey Tina Hesman, 2019, ScienceNews, retrieved on 9 Oct 2019 from https://www.sciencenews.org/article/nobel-prize-winner-david-baltimore-crisprbabies-ban

80. Sheldon S, Wilkinson S., 2004, Should selecting saviour siblings be banned? J Med Ethics 2004; 30: 533-537.

81. Silver Lee, 2000, Reprogenetics: third millennium speculation, EMBO Reports vol $1 /$ no 5, DOI: 10.1093/embo-reports/kvdog6

82. Silversides A. , 2007, Interface of private and public faces proposed cord blood bank. Canadian Medical Association Journal 2007; 177: 705.

83. Spriggs M, Savulescu J., 2002, "Saviour siblings". J Med Ethics 2002; 28: 289.

84. Spriggs, M., \& Savulescu, J. (2002). "Saviour siblings". Journal of medical ethics, 28(5), 289. doi:10.1136/jme.28.5.289

85. Sutcliffe AG, Ludwig M., 2007, Outcome of assisted reproduction. The Lancet 2007; 370, 351-359.

86. Swedin Eric, 2006, Designing Babies: A Eugenics Race with China, World Future Society

87. Turner R.J., Troya GN Turner, Gouni O. (edit), 2018, Prenatal Psychology: 100 Years, cosmoanelixis, https://www.amazon.com/Prenatal-Psychology-100-YearsExperience/dp/1984323822

88. Twisk M, Haadsma M, van der Veen F., 2007, Preimplantation genetic screening as an alternative to prenatal testing for Down syndrome: preferences of women undergoing in vitro fertilization/intracytoplasmic sperm injection treatment. Fertility and Sterility 2007; 88: 804-810.

89. Verlinsky Y, Rechitsky S, Schoolcraft W, Strom C, Kuliev A., 2001, Preimplantation Diagnosis for Fanconi Anemia Combined With HLA Matching. JAMA 2001; 285: 31303133.

90. Wolf SM, Kahn JP, Wagner JE., 2003, Using preimplantation genetic diagnosis to create a stem cell donor: issues, guidelines and limits. J Law Med Ethics 2003; 31: 327-339. 